\title{
Influence of Competence and Customer Service Motivation on the Performance of the Bank Syariah Mandiri Remittance Business Unit
}

\author{
Widhi Wicaksono \\ Universitas Pamulang \\ E-mail: $\underline{\text { dosen01049@unpam.ac.id }}$
}

Received: April-2019; Reviewed: May-2019; Accepted: Juny-2019;

Avalaibel Online: August-2019; Published: September -2019)

\begin{abstract}
Customer service plays an important role as the frontline in achieving the remittance business unit target. Bank Syariah Mandiri must be able to guarantee that customer service has adequate competence and high motivation in serving customers. This study aims to analyze the effect of competence and motivation of customer service on the performance of the remittance business unit. The object of research is 124 customer service in the region II Bank Syariah Mandiri. The method used in this study is Ordinary Least Square (OLS) on the SPSS 21 program. The results of this study indicate that the variable of competence and customer service motivation has a positive and significant impact on the performance of the remittance business unit.
\end{abstract}

Keywords: Competence; motivation, performance; customer service; ordinary least square (OLS), remittance.

\section{INTRODUCTION}

In Indonesia, there is a population that continues to grow 1-2\% per year making the number of people in Indonesia in the 2010 census reached 237 million people and $61 \%$ are of productive age (15-60 years). Of the 237 million inhabitants of Indonesia, $86 \%$ are Muslims, which means there are Muslim populations of 205 million. With the potential for emerging markets and a large Muslim population, the potential for Islamic banking to offer financial services in accordance with the spirit of spirituality in Allah SWT (Arifin, 2009; Horne, J.C. dan Wachowicz, 2007; Khusairi, 2015; Syukron, 2013).

Inversely related to the condition of the quality of human resources in Indonesia which is still very low in competitive value when compared to other countries. This, of course, shows the quality of competence, level of education and training in Indonesia is still very far from the proper and adequate category (Hasanah, Nanang Fattah, \& Eka Prihatin, 2010; Pakpahan, 2014; Sunarsi, 2016, 2017, 2018a, 2018c, 2018b). The main problem arises, namely the performance of every goal expected by the industry and the government has not been achieved. Banks are an 
industry that makes competitive advantage the most important thing, and therefore the competence and motivation of their employees is a major concern of the organization (Arifin, 2009; Astuti, Saleh, Baharuddin, \& Salam, 2016; Horne, J.C. dan Wachowicz, 2007; Nasrullah, Salam, Pratiwi, \& Niswaty, 2017; Niswaty, Rusbiati, Jamaluddin, \& Salam, 2017; Saggaf, Nasriyah, Salam, \& Wirawan, 2018; Salam, Akib, \& Daraba, 2018; Siringoringo, 2012; Yulianti, 2009).

Humans are resources that have thoughts and feelings that differentiate them from other factors of production. The difference in character and its role is very important, so the bank must always manage its production factors effectively and efficiently in order to be able to create excellence through human resources themselves in creating optimal work productivity (Busro, 2019; Handoko, 2011; Wirawan, 2015).

The main problem in Islamic banks, in general, is the lack of competence of each employee (Harin Ihtian, 2014; Kusumo, 2008; Mukhlis, 2012). This is because the Islamic Bank is a bank that is still very young in operation in Indonesia and even in the world. Islamic banking requires human resources who have high motivation to learn and always improve their abilities and skills in order to realize the expected performance. Good performance is very much needed in Islamic banking because it is a new player in the financial services industry. Efforts to forge human resources appropriately by observing the match between job demands and qualifications or abilities is a must. The level of capability and professionalism of existing Islamic bank employees must always be assessed back. Based on the assessment, an increase in the quality of Human Resources (HR) is carried out in accordance with the demands of work and responsibilities through education, motivation, training, and others.

In an era of fast-paced, practical and easy as now Islamic banking is demanded to be able to adjust to the rhythm that is proactive to changes very quickly. Improving the quality of human resources strategic to the skills, motivation, development, and management of talents is a major requirement in the era of globalization in realizing competitiveness and independence. In line with that vision and mission in the context of building the motivation and competence of Islamic banking HR must realize the importance of maintaining quality so that performance or productivity remains optimal. The key to achieving excellence in facing competition in an allpractical era. According to (Zulian, 2001) there are 4 things, namely realizing that all activities must be oriented to the quality of both the process and the output, always inspiring employees, involving employee enthusiasm in achieving common goals and applying the same principles in every line of the organization. This shows that good quality management is very dependent on the human resources involved. Without Islamic Bank employees who have competency requirements, a good Islamic banking system will never be realized. So that employee competence is an absolute requirement for the building of a glorious company performance (Danupranata, 2013; Kuniati, 2013; Triwahyuningtyas \& Ismail, 2017).

Competence is a very useful concept to explain why some people do their jobs better than others (Artini, 2015; Rahmisyari, 2017; Sedarmayanti, 2017; Sonny, 2012). Competence can help a person improve his performance and help to make decisions that enable employees to achieve their objectives.

\section{METHOD}

Data collection techniques used in this study are library research and field research. Testing is done by doing multiple linear regression analysis. Regression analysis is basically a study of the dependence of a dependent variable (dependent) with one or more independent variables (independent) with the aim of estimating and or predicting the population average or the average value of the dependent variable based on the known independent variable values. To test the variables in this study using the validity and reliability test, correlation test, classic assumption 
test and hypothesis test as follows: The Classic Assumption Test used in this study is the data normality test, multicollinearity, heteroscedasticity and using the autocorrelation test. Statistical tests use: Hypothesis Test, Coefficient of Determination $\left(\mathrm{r}^{2}\right)$, Statistical $\mathrm{t}$-test $\mathrm{t}$, Statistical F-test RESULT AND DISCUSSION

Sharia banking in Indonesia began to develop in 1999 when many conventional banks were affected by the economic crisis. Sharia banking appears as a bank that can reduce these negative effects. Sharia banking can reduce these effects because the underlying assets owned are real assets so there is no speculation aspect in circulating third party funds. Syariah banking in Indonesia is born and developed based on the wishes of the community as a form of religious maturity.

\section{Validity and Reliability Test}

Testing the validity of the instrument by testing the validity of the construction can be used the opinions of experts. After the instrument is constructed about aspects that will be measured based on certain theories. A validity test is a measure that shows the level of reliability of a measuring instrument. Based on the results of the validity test of the invalid competency variable, the numbers are $10,11,13,18,19$ and 24 , while the invalid motivation variables are $11,16,17$ and 23 , while for all the performance variables are valid. Determining this validity can be seen from the significance value below 0.05

The reliability test is the process of measuring the accuracy (consistency) of an instrument. This test is intended to ensure that the instrument used is an instrument that is reliable, consistent, stable and dependability, so that when used repeatedly it can produce the same data. The Cronbach Alpha competency score is 0.904, the motivation value is 0.913, and the performance value is 0.914 . Judging from the Cronbachs alpha value above 0.60 expressed reliable

\section{Correlation Test between Variables}

Correlation analysis used is the Pearson product moment (r) correlation because it is often used by researchers. This correlation was stated by Karl Pearson in 1990. Its purpose is to determine the degree of relationship between the independent variable and the dependent variable. In (Sugiyono, 2016)the interpretation of the correlation coefficient is shown as follows

Table 1.

Interpretation of Pearson coefficients

\begin{tabular}{cl}
\hline Coefficient interval & Relationship Level \\
\hline $0,80-1,00$ & Very strong \\
$0,60-0,79$ & Strong \\
$0,40-0,59$ & Strong enough \\
$0,20-0,39$ & Low \\
$0,00-0,19$ & Very low \\
\hline
\end{tabular}

When viewed from the Pearson test values can be described correlation of independent variables and independent variables of the study, the competency variable has a value of 0.787 which is included in the category of strong correlation with performance. Motivation variable has a value of 0.756 which is included in the category of strong correlation with performance. 
The competency variable has a value of 0.697 which is included in the category of strong correlation with motivation.

Table 2.

Correlation test between variables Correlations

\begin{tabular}{|c|c|c|c|c|}
\hline & & $\begin{array}{c}\text { Employee } \\
\text { Performance }\end{array}$ & Competency & Motivation \\
\hline & $\begin{array}{l}\text { Employee } \\
\text { Performance }\end{array}$ & 1,000 & ,787 & ,756 \\
\hline \multicolumn{5}{|l|}{ Pearson Correlation } \\
\hline & Competency & ,787 & 1,000 & ,697 \\
\hline & Motivation & ,756 & 697 & 1,000 \\
\hline & $\begin{array}{l}\text { Employee } \\
\text { Performance }\end{array}$ & . &, 000 &, 000 \\
\hline \multicolumn{5}{|l|}{ Sig. (1-tailed) } \\
\hline & Competency & ,000 & & ,000 \\
\hline & Motivation &, 000 & 000 & \\
\hline & $\begin{array}{l}\text { Employee } \\
\text { Performance }\end{array}$ & 124 & 124 & 124 \\
\hline \multicolumn{5}{|l|}{$\mathrm{N}$} \\
\hline & Competency & 124 & 124 & 124 \\
\hline & Motivation & 124 & 124 & 124 \\
\hline
\end{tabular}

\section{Classic Assumption Test}

Normality testing aims to test whether in the regression model the dependent variable, the independent variable or both have normal distribution or not. A good regression model is a normal or near-normal distribution. One way to test normality is to look at a normal probability plot graph.

In principle, normality can be detected by looking at the spread of data (points) on the diagonal axis of the graph. From the picture above it can be seen that the data spread around the diagonal line and follows the direction of the diagonal line, then the regression model meets the assumption of normality (Ghozali, 2016)

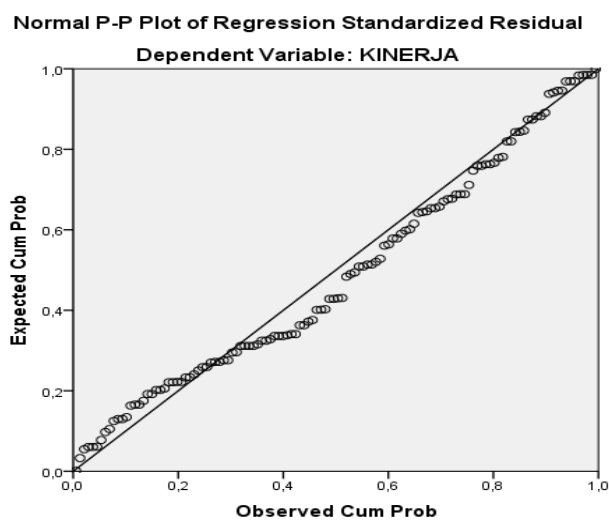

Figure 1

Graph Analysis Normality Test 
You can also use the Kolmogorov-Smirnov formal test to see the normality of the data. Based on the Kolmogorov-Smirnov normality test, it can be seen that "test distribution is normal" means that the data used in this study has a normal distribution.

Table 3.

Kolmogorov Smirnov Test

\begin{tabular}{|ll|c|c|c|}
\hline \multicolumn{2}{|c|}{ One-Sample Kolmogorov-Smirnov Test } \\
\hline N & & Competency & Motivation & $\begin{array}{c}\text { Employee } \\
\text { Performance }\end{array}$ \\
Normal Parameters & & & & \\
& & 124 & 124 & 124 \\
& Mean & 3,9490 & 3,8719 & 3,9200 \\
Most Extreme Differences & Std. Deviation &, 40774 &, 44408 &, 40036 \\
& Absolute &, 091 &, 070 &, 121 \\
Kolmogorov-Smirnov Z & Positive &, 060 &, 062 &, 121 \\
Asymp. Sig. (2-tailed) & Negative &,- 091 &,- 070 &,- 059 \\
& & 1,018 &, 778 & 1,347 \\
\hline
\end{tabular}

a. Test distribution is Normal.

b. Calculated from data.

Multicollinearity test aims to test whether the regression model found a correlation between independent variables.

To test the presence or absence of multicollinearity in the regression model can be seen from the value of tolerance and variance inflation factor (VIF). A multicollinearity-free regression model has a VIF value ranging from 1 to 10 and has a tolerance figure above 0.10 .

Based on multicollinearity testing in table 4.4 below, tolerance values above 0.10 and VIF below 10 are obtained, so it can be said that there is no multicollinearity. In (Nachrowi, 2006: 143) tolerance values close to 1 and VIF no more than 5 is considered not to contain Multicollinearity.

Table 4

Multicollinearity Test

Coefficients $^{\mathrm{a}}$

\begin{tabular}{|c|c|c|c|c|c|c|c|}
\hline \multirow[t]{2}{*}{ Model } & \multicolumn{2}{|c|}{ Unstandardized Coefficients } & \multirow{2}{*}{$\begin{array}{c}\begin{array}{c}\text { Standardized } \\
\text { Coefficients }\end{array} \\
\text { Beta }\end{array}$} & \multirow[t]{2}{*}{$\mathrm{t}$} & \multirow[t]{2}{*}{ Sig. } & \multicolumn{2}{|c|}{ Collinearity Statistics } \\
\hline & B & Std. Error & & & & Tolerance & VIF \\
\hline (Constant) &, 551 & ,201 & & 2,746 & 007 & & \\
\hline Competency & ,496 &, 068 &, 506 & 7,314 &, 000 &, 514 & 1,946 \\
\hline Motivation & ,364 & ,062 & ,404 & 5,839 &, 000 & ,514 & 1,946 \\
\hline
\end{tabular}

a. Dependent Variable: Employee Performance

Multicollinearity test aims to test whether the regression model found a correlation between the independent variables (independent).

Autocorrelation test aims to test whether in a linear regression model there is a correlation between observations in one variable. A good regression model is free from autocorrelation. Test this classic assumption of autocorrelation by using the Durbin Watson test. 
Table 5.

AutoCorrelation Test

Model Summary ${ }^{b}$

\begin{tabular}{cccccc}
\hline Model & $\mathrm{R}$ & $\mathrm{R}$ Square & $\begin{array}{c}\text { Adjusted } \mathrm{R} \\
\text { Square }\end{array}$ & $\begin{array}{c}\text { Std. Error of the } \\
\text { Estimate }\end{array}$ & $\begin{array}{c}\text { Durbin- } \\
\text { Watson }\end{array}$ \\
\hline 1 &, $838^{\mathrm{a}}$ &, 703 &, 698 &, 22001 & 2,047 \\
\hline
\end{tabular}

a. Predictors: (Constant), Motivation, Competency

b. Dependent Variable: Employee Performance

Based on table 5 above, the Durbin Watson (DW) value of 2.0 is obtained where the value is still around the $\mathrm{DW} \pm 2$ statistical value, then $\rho$ will be 0 which means no autocorrelation symptoms occur in the model created in this study.

It aims to test whether in the regression model there is an inequality of variance from one observation to another. A good regression model is if heteroscedasticity does not occur. To test the presence or absence of heteroscedasticity can be done by looking at the scatter plot graph.

Based on Figure 4.2 heteroscedasticity test scatter plot graph; It can be seen that the data distribution is around zero point and spread randomly or not form a certain clear pattern. Thus it can be concluded that there is no heteroscedasticity in the regression pattern so that the regression model is feasible to use.

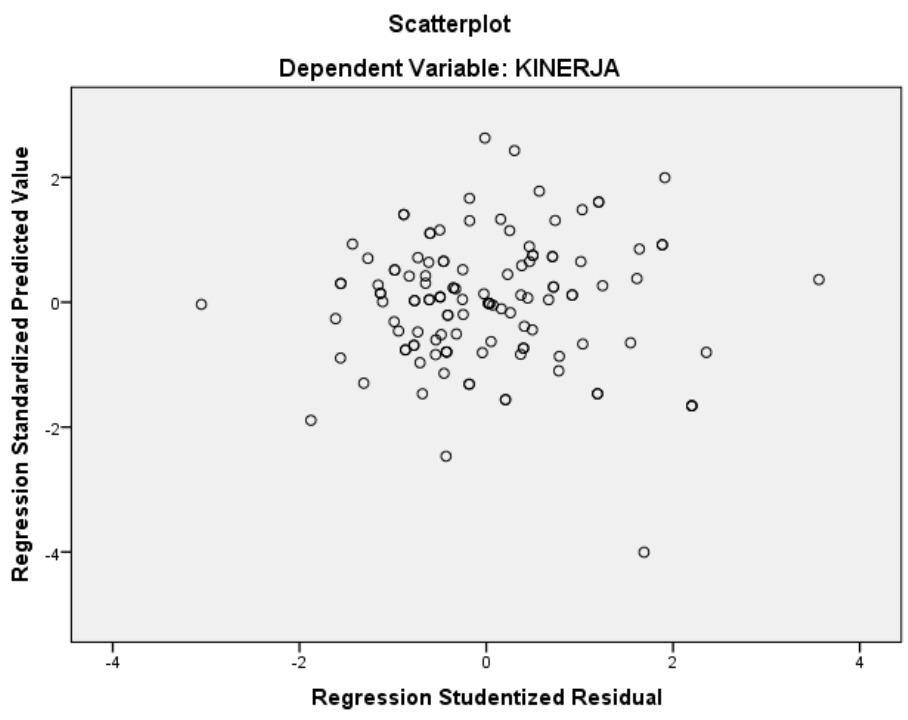

Figure 2

Heteroskedasticity Test

\section{Hypotesis Test}

This test is conducted to determine whether the hypothesis that has been set is accepted or rejected statistically. The research hypothesis testing was carried out using the t statistical test, $\mathrm{F}$ statistical test and R square statistical test, the following are the models used for hypothesis testing: 
$\mathrm{Y}=\alpha 0+\beta 1$ Kompetensi $+\beta 2$ Motivasi

Correlation ( $\mathrm{R})$ is done to measure the strength of the relationship between two variables. The coefficient of determination $\left(\mathrm{r}^{2}\right)$ is done to measure how far the model's ability to explain the dependent variable (Ghazali, 2001: 123).

Table 6.

Coefficient Determination Analysis

\begin{tabular}{cccccc} 
Model & $\mathrm{R}$ & R Square & $\begin{array}{c}\text { Adjusted R } \\
\text { Square }\end{array}$ & $\begin{array}{c}\text { Std. Error of the } \\
\text { Estimate }\end{array}$ & $\begin{array}{c}\text { Durbin- } \\
\text { Watson }\end{array}$ \\
\hline 1 &, $838^{\mathrm{a}}$ &, 703 &, 698 &, 22001 & 2,047 \\
\hline
\end{tabular}

a. Predictors: (Constant), Motivation, Competency

b. Dependent Variable: Employee Performance

Based on the output display in table 4.8 it can be seen that the value of $\mathrm{R}$ is $83.8 \%$ which shows that there is a very strong influence. $\mathrm{R}$ square value of $70.3 \%$ and Adjusted $\mathrm{R}$ Square value of $69.8 \%$. This means that the adjusted value of the coefficient of determination is 0.698 which means as much as $69.8 \%$ dependent variation (Performance) can be explained or influenced by independent variations (Competence and Motivation). While the remaining $30.2 \%$ is influenced by other variables outside the variables studied.

T-test aims to determine the effect of independent variables namely Competence and Motivation on Performance

Table 7.

T-test

Coefficients $^{\mathrm{a}}$

\begin{tabular}{|c|c|c|c|c|c|c|c|c|}
\hline \multirow{2}{*}{\multicolumn{2}{|c|}{ Model }} & \multicolumn{2}{|c|}{$\begin{array}{l}\text { Unstandardized } \\
\text { Coefficients }\end{array}$} & $\begin{array}{l}\text { Standardized } \\
\text { Coefficients }\end{array}$ & \multirow[t]{2}{*}{$\mathrm{t}$} & \multirow[t]{2}{*}{ Sig. } & \multicolumn{2}{|c|}{ Collinearity Statistics } \\
\hline & & B & Std. Error & Beta & & & Tolerance & VIF \\
\hline \multirow{3}{*}{1} & (Constant) &, 551 & ,201 & & 2,746 & ,007 & & \\
\hline & Competency & ,496 & ,068 & ,506 & 7,314 & , 000 &, 514 & 1,946 \\
\hline & Motivation & ,364 &, 062 & ,404 & 5,839 & ,000 &, 514 & 1,946 \\
\hline
\end{tabular}

a. Dependent Variable: Employee Performance

The Competency variable has a significance value of 0,000 because the significance value is smaller than 0.05 then $\mathrm{H} 1$ is accepted. So it can be said that competence has a significant effect on performance.

Motivation variable has a significance number of 0,000 because the significance value is greater than 0.05 then $\mathrm{H} 1$ is accepted. So it can be said that motivation significantly influences performance.

This simultaneous test is carried out to test the effect of together the independent variables on the dependent variable. 
Table 8.

F test

\begin{tabular}{|c|c|c|c|c|c|c|}
\hline \multicolumn{7}{|c|}{ ANOVA $^{a}$} \\
\hline Model & & Sum of Squares & df & Mean Square & $\mathrm{F}$ & Sig. \\
\hline \multirow{3}{*}{1} & Regression & 13,858 & 2 & 6,929 & 143,155 &, $000^{\mathrm{b}}$ \\
\hline & Residual & 5,857 & 121 &, 048 & & \\
\hline & Total & 19,715 & 123 & & & \\
\hline
\end{tabular}

a. Dependent Variable: Employee Performance

b. Predictors: (Constant), Motivation, Competency

Based on the results of the F statistical tests in table 4.10 obtained an F count of 143.155 with a significance level of 0.000 . This means that simultaneously (together) there is the influence of the Competency and Motivation variables on Performance.

Performance $=0.551+0.496$ Competencies +0.364 Motivation

\section{CONCLUSION}

The magnitude of the simultaneous influence between competency variables and customer service motivation on the performance of the Bank Syariah Mandiri remittance business unit in regional office 2 which includes Jabodetabek is quite strong. While the contribution together competency and motivation variables on performance by $69.8 \%$ while the effect is influenced by other variables not explained in this study.

\section{REFERENCES}

Arifin, Z. (2009). Dasar-dasar Manajemen Bank Syariah. In Pustaka Alvabet.

Artini, Y. D. (2015). Manajemen Sumber Daya Manusia (MSDM) Berbasis Kompetensi sebagai Strategi Membangun Organisasi Kompetitif. EFISIENSI - KAJIAN ILMU ADMINISTRASI. https://doi.org/10.21831/efisiensi.v11i2.3989

Astuti, A., Saleh, S., Baharuddin, A., \& Salam, R. (2016). Studi Motivasi Kerja Pegawai pada PT. Bank Sulselbar Cabang Utama Makassar. JURNAL ILMU ADMINISTRASI PERKANTORAN (JIAP), 79-88.

Busro, M. D. (2019). Teori-teori Manajemen Sumber Daya Manusia. In Teori-teori Manajemen Sumber Daya Manusia.

Danupranata, G. (2013). Buku Ajar Manajemen Perbankan Syariah. In Salemba Empat.

Ghozali, I. (2016). Aplikasi Analisis Multivariate dengan Program IBM SPSS 21 :Update PLS Regresi. Semarang. https://doi.org/10.2307/1579941

Handoko, T. H. (2011). Manajemen Personalia dan Sumber Daya Manusia. Pengantar Manajemen.

Harin Ihtian. (2014). Pengaruh Motivasi kerja, lingkungan kerja, dan budaya organisasi terhadap kinerja karyawan dan dampaknya pada kinerja Bank Aceh Syariah di Kota Banda Aceh. Jurnal Magister Manajemen.

Hasanah, D. S., Nanang Fattah, \& Eka Prihatin. (2010). Pengaruh Pendidikan Latihan (DIKLAT) Kepemimpinan Guru dan Iklim Kerja Terhadap Kinerja Guru Sekolah Dasar 
SE Kecamatan Babakancikao Kabupaten Purwakarta. pendidikan.

Horne, J.C. dan Wachowicz, J. M. (2007). Prinsip-Prinsip Manajemen Keuangan. In PrinsipPrinsip Manajemen Keuangan. https://doi.org/10.4324/9781315641348

Khusairi, H. (2015). Hukum Perbankan Syariah. Al-Qisthu: Jurnal Kajian Ilmu-ilmu Hukum. https://doi.org/10.32694/010120

Kuniati. (2013). Analisis Perbandingan Kinerja Bank Syariah dan Bank Konvensional. Junal Ekonomi dan Kewirausahaan.

Kusumo, Y. A. (2008). Analisis Kinerja Keuangan Bank Syariah Mandiri Periode 2002 - 2007 (dengan Pendekatan PBI No. 9/1/PBI/2007). La_Riba. https://doi.org/10.20885/lariba.vol2.iss1.art8

Mukhlis, I. (2012). Kinerja Keuangan Bank Dan Stabilitas Makroekonomi Terhadap Profitabilitas Bank Syariah Di Indonesia. Jurnal Keuangan dan Perbankan.

Nasrullah, M., Salam, R., Pratiwi, D., \& Niswaty, R. (2017). Motivasi Kerja Pegawai Di Kantor Keyahbandaran Utama Makassar. Jurnal Ilmiah Manajemen Dan Bisnis, 18(2), 206-211.

Niswaty, R., Rusbiati, S., Jamaluddin, J., \& Salam, R. (2017). The Influence of Teacher's Reinforcement for Students Motivation. International Conference on Education, Science, Art and Technology, 148-152.

Pakpahan, E. S. (2014). Pengaruh Pendidikan Dan Pelatihan Terhadap Kinerja Pegawai (Studi Pada Badan Kepegawaian Daerah Kota Malang). Jurnal Administrasi Publik Mahasiswa Universitas Brawijaya.

Rahmisyari, R. (2017). Pengaruh Kompetensi dan Lingkungan Kerja Terhadap Kinerja Pegawai. Jurnal Manajemen dan Bisnis Indonesia. https://doi.org/10.31843/jmbi.v5i1.139

Saggaf, M. S., Nasriyah, N., Salam, R., \& Wirawan, H. (2018). The Influence of Teacher's Pedagogic Competence on Learning Motivation of Student of Office Administration Expertise Package.

Salam, R., Akib, H., \& Daraba, D. (2018). Utilization of Learning Media In Motivating Student Learning.

Sedarmayanti. (2017). Manajemen Sumber Daya Manusia. In Manajemen Sumber Daya Manusia.

Siringoringo, R. (2012). Perbankan Di Indonesia. Buletin Ekonomi Moneter Dan Perbankan.

Sonny, H. (2012). Analisis Pengaruh Pengembangan SDM Terhadap Kinerja Pegawai Pada Badan Kepegawaian Daerah Kabupaten Karawang. Jurnal Manajemen.

Sugiyono. (2016). Metode Penelitian dan Pengembangan (Research and Development/R\&D). In Bandung: Alfabeta. https://doi.org/10.1016/j.drudis.2010.11.005

Sunarsi, D. (2016). Pengaruh Minat, Motivasi Dan Kecerdasan Kognitif Terhadap Prestasi Belajar (Studi Kasus Pada Mahasiswa Program Studi S-1 Manajemen. Fakultas Ekonomi. Universitas Pamulang. Thn. Akademik 2015-2016). Proceedings, 1(1).

Sunarsi, D. (2017). Pengaruh Disiplin, Motivasi, Dan Kompetensi Terhadap Prestasi Belajar (Studi Kasus Pada Mahasiswa Universitas Pamulang, Tangerang Selatan Tahun Akademik 2016-2017). Jurnal Mandiri: Ilmu Pengetahuan, Seni, dan Teknologi, 1(2), 207-226.

Sunarsi, D. (2018a). Analisis Motivasi Kerja Tenaga Pendidik Sukarela Pada Pusat Kegiatan 
Belajar Masyarakat (PKBM) Bimasda Kota Tangerang Selatan. Kreatif: Jurnal Ilmiah Prodi Manajemen Universitas Pamulang, 6(2), 53-65.

Sunarsi, D. (2018b). Pengaruh Gaya Kepemimpinan, Motivasi Dan Disiplin Kerja Terhadap Kinerja Pendidik Yayasan Marvin. Inovasi, 5(1), 1-18.

Sunarsi, D. (2018c). Pengaruh Motivasi Dan Disiplin Terhadap Produktivitas Kerja Karyawan Pada PT. Nadi Suwarna Bumi. Jurnal Semarak, 1(1).

Syukron, A. (2013). Dinamika Perkembangan Perbankan Syariah Di Indonesia. Jurnal Ekonomi dan Hukum Islam.

Triwahyuningtyas, E., \& Ismail. (2017). Analisis Kinerja Keuangan Bank Umum Syariah Dan Faktor Yang Mempengaruhinya. e-Jurnal Manajemen Kinerja. https://doi.org/2407-7305

Wirawan. (2015). Manajemen Sumber Daya Manusia Indonesia. In Depok.

Yulianti, R. T. (2009). Manajemen Risiko Perbankan Syari'ah. La_Riba. https://doi.org/10.20885/lariba.vol3.iss2.art2

Zulian, Y. (2001). Manajemen Kualitas Produk dan Jasa. In Ekonomi dan Bisnis. 
Widhi Wicaksono; Influence of Competence and Customer Service Motivation ...|103 